\title{
Resolusi Konflik melalui Model Pengampunan Vita Activa Arendt dalam Komunikasi Generasi Muda Kalimantan Barat
}

\author{
Joshua Fernando, Rustono Farady Marta \\ Program Pascasarjana, Magister Ilmu Komunikasi - Universitas Bunda Mulia, \\ Jl. Lodan Raya No.2, Jakarta Utara 14430, \\ No. HP: +628231100 4296; +6285232961203 \\ Email: joshuafernandosaty@gmail.com dan rustonofarady@gmail.com
}

\begin{abstract}
The life of a cultural society cannot be avoided by potential conflicts that arise at any time. West Kalimantan has a history of inter-ethnic conflict, which is currently still undergoing a recovery phase. The young generation is the subject that encourages harmony in West Kalimantan. This study aims to find a model of the forgiveness process of past ethnic conflicts that occur in the young generation of West Kalimantan. This study was examined using a qualitative method through an explorative phenomenological study with the phenomenological perspective of forgiveness Hannah Arendt. The results of this study indicate that the collective relationships built by the younger generation and the occurrence of cultural acculturation help in the process of natural forgiveness. On the other hand, forgiveness is not fully realized due to the occurrence of collections of collective memory such as stereotypes, past stories, and exposure to charged media content about past ethnic conflicts in the young generation of West Kalimantan. The substance of this study is in the form of policy recommendations on the role of the community, traditional leaders, and regional governments collaborating to achieve just and prosperous reconciliation in West Kalimantan.
\end{abstract}

Keywords: Model of Forgiveness, Phenomenology, Arendt, Young Generation

\begin{abstract}
Abstrak
Kehidupan masyarakat budaya tidak dapat terhindarkan dari potensi konflik yang muncul kapan saja. Kalimantan Barat memiliki sejarah konflik antar etnis yang saat ini masih melalui tahap pemulihan. Generasi muda menjadi subjek yang mendorong terjadinya keharmonisan di Kalimantan Barat. Penelitian ini bertujuan untuk menemukan model proses pengampunan atas konflik etnis masa lalu terjadi pada generasi muda Kalimantan Barat. Penelitian ini dikaji dengan menggunakan metode kualitatif melalui studi fenomenologi bersifat eksploratif dengan perspektif fenomenologi pengampunan Hannah Arendt. Hasil penelitian ini menunjukkan hubungan kolektif yang dibangun generasi muda dan terjadinya akulturasi budaya membantu dalam proses pengampunan secara alamiah. Di sisi lain, pengampunan tidak seutuhnya terwujud dikarenakan terjadinya kumpulan memori kolektif seperti stereotip, cerita masa lalu, dan paparan konten media yang bermuatan mengenai konflik etnis masa lalu pada generasi muda Kalimantan Barat. Substansi penelitian ini berupa rekomendasi kebijakan peran masyarakat, tokoh adat, dan pemerintah daerah berkolaborasi untuk tercapainya rekonsiliasi yang adil dan makmur di Kalimantan Barat.
\end{abstract}

Kata kunci: Model Pengampunan, Fenomenologi, Arendt, Generasi Muda

\section{Pendahuluan}

Komunikasi dalam perbedaan budaya tidak menjadi halangan untuk satu sama lain menjalin hubungan (relationship), yang terpenting adalah saling memahami (understanding), saling beradaptasi (adaptation) dan saling bertoleransi (tolerance). Kunci utama dari pergaulan antarbudaya adalah tidak menilai orang lain yang berbeda budaya dengan menggunakan penilaian budaya sendiri (Aminullah et al, 2015).

Komunikasi merupakan tali penghubung untuk menghadirkan keharmonisan dalam 
sebuah kelompok. Harmonis adalah keadaan dimana antara satu individu dengan individu lainnya saling seia sekata, atau dapat dikatakan perbedaan antara individu itu sudah terkikis oleh sikap tenggang rasa dan toleransi yang baik (Anshorie et al., 2015).

Keharmonisan yang terjadi tidak selalu berjalan dengan baik. Ironisnya konflik etnis dapat terjadi dikarenakan adanya permasalahan pribadi yang melibatkan dua orang atau lebih yang selama ini memendam rasa tidak suka, tersaingi, dirugikan, dan permasalahan lainnya (Prayudi, 2004:40).

Konflik antara etnis Dayak dan Madura juga tidak kalah dahsyatnya selama kurun waktu 1950-1999, setidaknya sudah terjadi sebanyak 13 kali (Supriyadi, 2011). Awalmula terjadi konflik etnis antara Dayak dan Madura diakibatkan adanya persaingan secara ekonomi dimana etnis Madura datang sebagai pedagang dan mendominasi perekonomian masyarakat lokal di daerah Sampit, Kalimantan Tengah (Prayudi, 2004:47-48).

Arkanudin (2006) menjelaskan bahwa konflik Dayak dan Madura di wilayah Kalimantan Barat bukan mayoritas disebabkan oleh hal ekonomi, politik, dan hankamnas melainkan oleh adanya permasalahan di bidang sosial dan budaya, sehingga masalah perbedaan sosial tersebut diidentifikasi mengenai faktor terjadinya konflik antara etnis Dayak dan Madura, seperti tabel 1.

Konflik terbesar tercatat pada tahun 1997 yang sebagian besar terjadi di wilayah Kalimantan Barat, kemudian salah satu konflik yang besar terjadi antar etnis Melayu

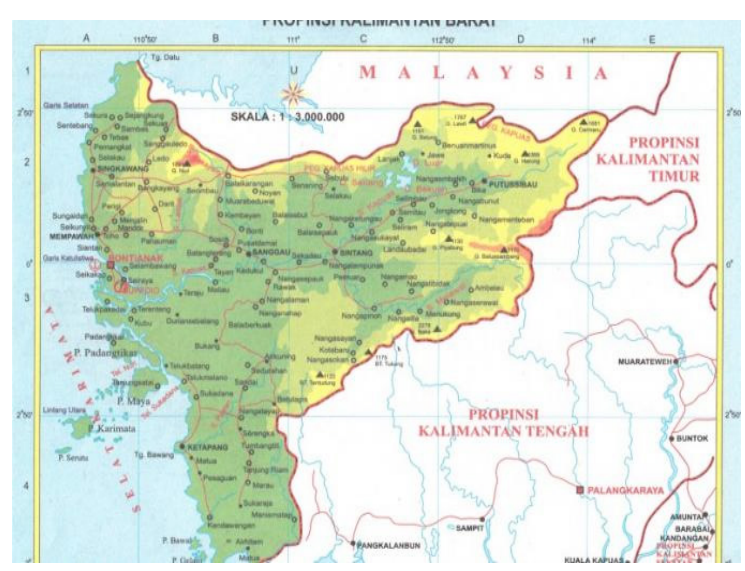

Gambar 1 Provinsi Kalimantan Barat Sumber: Rahino, 2017

dan Madura. Latar belakang konflik tersebut adanya indikasi pembunuhan salah satu masyarakat etnis Melayu oleh Etnis Madura pada tahun 1999, sehingga sekitar 48.000 masyarakat mengungsi di sekitar daerah Kota Pontianak dan Kabupaten Pontianak (Subro, 2011:20).

Penduduk Kalimantan Barat menurut data terakhir tahun 2010 dari Badan Pusat Statistik sebanyak 4.395.983 jiwa dan sebanyak 1.802.247 merupakan generasi muda usia 0-19 tahun. Saat ini, seluruh anak di bawah 18 tahun merupakan anggota organisasi Forum Anak Kalimantan Barat yang di dalamnya dibagi menjadi willayah empat belas kabupaten dan kota (Sumber: Data BPS, 2010).

Yusriadi (2008) dalam Zakiyah (2017:192) memaparkan keragaman etnis tersebut terekam dalam data BPS tahun 2000 yaitu dari 3.732.419 penduduk daerah Kalimantan Barat terdapat 444.929 orang Sambas (Melayu), 352.937 orang Tionghoa, 341.173 orang Jawa, 275.914 orang Darat, 203.612 orang Madura, 178.933 orang Pesaguan, dan lainnya berjumlah 1.362.424 orang. Populasi generasi muda Kalimantan 
Tabel 1. Faktor-faktor Penyebab Konflik

\begin{tabular}{|c|c|c|}
\hline Identifikasi Faktor & Dayak & Madura \\
\hline Pola Pemukman & Huma Betang & Tanean Lanjang \\
\hline Lokasi Pemukiman & Perdesaan & Perkotaan/Perdesaan \\
\hline Pekerjaan & Peladang, Peramu, PNS & $\begin{array}{l}\text { Pedagang, Buruh Kasar, } \\
\text { dan Petani }\end{array}$ \\
\hline Pendidikan & Rendah, Sedang, Tinggi & Rendah \\
\hline Pelapisan Sosial & Egaliter & Keagamaan dan Kekayaan \\
\hline Kebiasaan & $\begin{array}{l}\text { Musyawarah, Mengalah, } \\
\text { dan Jujur }\end{array}$ & $\begin{array}{l}\text { Membawa senjata tajam, } \\
\text { Solidaritas, yang membabi buta, } \\
\text { Inkar janji }\end{array}$ \\
\hline Prasangka & $\begin{array}{l}\text { Pemalas, Rawan dendam, } \\
\text { Tidak materialistis }\end{array}$ & $\begin{array}{l}\text { Pembuat onar, penyerobot lahan } \\
\text { dan Pelangar hukum, Pedendam, } \\
\text { Preman }\end{array}$ \\
\hline
\end{tabular}

Sumber: Arkanudin, 2006 : 190

Barat yang terdiri dari masyarakat berbagai latar belakang etnis semakin meningkat, membuat penelitian ini menjadi menarik dengan sejarah konflik etnis yang pernah terjadi di Kalimantan Barat.

Tidak dapat dipungkiri identitas generasi muda sebagai masyarakat etnis dapat mempengaruhi transisi saat memasuki berbagai aspek kehidupan termasuk mengakses segala sumber daya di Kalimantan Barat (Minza, 2012:154). Sehingga, kontribusi generasi muda sebagai bagian dari proses rekonsiliasi masyarakat Kalimantan Barat sangat kuat, untuk itu proses pengampunan generasi muda mengenai konflik etnis masa lalu perlu diperhatikan. Meskipun tidak mengalami secara langsung, generasi muda Kalimantan Barat rentan akan paparan stereotip yang menyudutkan salah satu etnis sehingga bisa menjadi pemantik adanya konflik yang bisa terjadi sewaktu-waktu.
Indah (2016:289), menjelaskan mengenai konsep pengampunan Hannah Arendt berasal dari filsafat tindakan yang berasal dari konsep vita activa, dalam hal ini konsep vita activa merumuskan tiga aktivitas manusia, antara lain : kerja, karya dan tindakan. Arendt (1958:7) menjelaskan bahwa:

"With the term vita activa, I propose to designate three fundamental human activities: labor, work and action. They are fundamental because each corresponds to one of the basic conditions under which life on earth has been given to man. Labor is the activity which corresponds to the biological process of the human body. Work is the activity which corresponds to unnaturalness of human existence, which is not imbedded in, and whose mortality is not compensated by, the species ever-recurring life cycle. Action, the only activity that goes on directly between men without the intermediary of things or matter, corresponds to the human condition plurality, to the fact that men, not Man, live on the earth and inhabit the world".

Indah (2016: 296-297) mengungkapkan mengenai setiap orang dalam ranah tindakan mempunyai pemahaman bahwa, setiap orang mempunyai gagasan masing-masing. 
Keberbedaan dalam hal ini dipahami untuk menghindari kesalahpahaman dalam bertindak, sehingga berpikir melalui perspektif orang lain menjadi tindakan pentingdidalamkebersamaan.Padadasarnya, ketika manusia melakukan tindakan wicara sangat sulit untuk mengembalikannya ke titik nol, untuk itu, Arendt menawarkan kondisi mengenai pengampunan sehingga dengan mengampuni maka manusia akan mampu membuka lembaran yang baru.

Ampunan juga dapat mengatasi dendam-dendam masa lalu, karena dengan mengampuni maka seseorang memberikan kesempatan baru bagi orang lain untuk instropeksi dan memulai kehidupan baru. Mengampuni merupakan tindakan yang dilakukan untuk melawan kesalahan atau dosa. Mengampuni adalah tindakan di mana salah satu orang memberikan ampunan, sementara yang lainnya menerima ampunan (Indah, 2016:296).

Arendt (1958: 242) menjelaskan bahwa hanya cinta yang mampu mengampuni karena hanya cinta yang benar-benar menerima kesalahan seseorang. Arendt menawarkan bukan hanya cinta, namun juga rasa hormat. Rasa hormat berarti bahwa adanya persahabatan antara dua orang atau lebih, tanpa hubungan seksual. Rasa hormat di sini menekankan pada hubungan persahabatan, yang tidak hanya didasari oleh cinta, namun juga rasa pertemanan.

Arendt melangkah lebih jauh dengan mengatakan, memaafkan berfungsi untuk membatalkan perbuatan masa lalu (Arendt 1958:237). Deskripsi Arendt berfokus pada unsur-unsur pengampunan yang aktif. Memaafkan berarti membebaskan yang lain dari konsekuensi tindakannya, berkomitmen untuk bertindak dengan cara yang tidak ditentukan oleh permusuhan yang ditimbulkan oleh pelanggaran, dan dengan demikian memulai dan mengundang masa depan yang baru (Pettigrove, 2006).

Kisah pengampunan yang mengambil bentuk sejauh ini melibatkan tiga elemen. Ini melibatkan, 1) membebaskan si pelanggar dari konsekuensi tindakannya, yang pada gilirannya melibatkan 2) komitmen untuk tidak bertindak dari permusuhan yang berakar pada pelanggaran, dan 3) pengurangan terakhir dari permusuhan tersebut. Untuk hal ini, Arendt menambahkan dua kondisi lebih lanjut. Pertama, pelanggaran yang dimaafkan pasti "dilakukan tanpa sadar." Kedua, memaafkan dilakukan demi yang dimaafkan. (Arendt 1958 : 240). Peneliti mengambil beberapa penelitian terdahulu untuk melihat kebaruan dalam penelitian ini. Adapun state of the art dalam penelitian ini seperti tabel 2.

Jasson dan Wagman (Jansson et al., 2017) membahas mengenai relevansi Vita Activa dalam dunia pekerjaan sehingga adanya perspektif yang mendalam secara filosofis mengenai pekerjaan manusia. Kreber (Kreber, 2014) membahas dari sisi penggunaan Vita Activa untuk membentuk pemahaman profesionalisme yang berwawasan sipil untuk menjadikan individu yang siap dengan adanya perubahan. Di sisi lain, Haba (Haba, 2012) menjelaskan mengenai interaksi masyarakat Madura, Dayak dan Melayu di lokasi konflik Kalimantan Barat terus membaik dan 
Tabel 2. State of the art

\begin{tabular}{ll}
\hline \multicolumn{1}{c}{ Judul Artikel Jurnal Ilmiah } & \multicolumn{1}{c}{ Penulis dan Tahun } \\
\hline $\begin{array}{l}\text { Hannah Arendt's vita activa: A valuable } \\
\text { contribution to occupational science }\end{array}$ & Jansson \& Wagman (2017) \\
$\begin{array}{l}\text { The 'Civic-minded' Professional? An } \\
\text { exploration through Hannah Arendt's }\end{array}$ & Kreber (2014) \\
'vita activa' & \\
$\begin{array}{l}\text { Etnisitas, Hubungan Sosial dan Konflik } \\
\text { di Kalimantan Barat }\end{array}$ & Haba (2012) \\
$\begin{array}{l}\text { Prospek Pembangunan Masyarakat } \\
\text { Pasca Konflik Sambas }\end{array}$ & Ulum (2013) \\
\hline
\end{tabular}

Sumber: Olahan Peneliti, 2018

(Ulum, 2013) meneliti mengenai relokasi sebagai bagian dari strategi untuk mencapai rekonsiliasi sosial melalui diplomasi budaya sehingga adanya upaya-upaya yang dilakukan untuk membangun masyarakat baru.

Keempat peneltian terdahulu menjelaskan mengenai penerapan Vita Activa dan kehidupan pasca konflik etnis. Dalam penelitian ini peneliti ingin melihat bagaimana Vita Activa Arendt dapat diterapkan dalam kehidupan masyarakat pasca konflik etnis di Kalimantan Barat, sehingga hal ini dirasa perlu dikaji secara mendalam untuk menjadi bagian dari proses rekonsiliasi yang masih terus berjalan. Tujuan penelitian ini untuk menemukan model proses pengampunan konflik etnis masa lalu terjadi pada generasi muda Kalimantan Barat.

\section{Metode Penelitian}

Penelitian ini menggunakan metode penelitian fenomenologi (Ahimsa-Putra, 2012:275) menjelaskan fenomenologi dimana adanya kesadaran yang selalu diarahkan kepada 'dunia kehidupan' (life world), dan dunia ini tidak lain merupakan sebuah dunia antarsubjek (intersubjective) yang berarti manusia yang berada dalam dunia tersebut saling berhubungan, sehingga kesadaran yang terbentuk di antara mereka bersifat sosial atau dimiliki bersama. Pengalaman pribadi dalam 'dunia' tersebut beserta pengalaman orang-orang lain merupakan pengalaman bersama. Penelitian ini ingin melihat bagaimana proses kesadaran individu mengenai pengampunan atas konflik etnis masa lalu di Kalimantan Barat dengan adanya proses pengampunan secara individu yang dialami oleh generasi muda Kalimantan Barat dari perspektif fenomenologi.

Pengumpulan data pada penelitian ini menggunakan wawancara mendalam yang terfokus (in-depth-focused interview) kepada para informan berasal dari anggota Forum Anak Kalimantan Barat yang dipilih berdasarkan anak keturunan masyarakat etnis yang pernah berkonflik serta beberapa informan pendukung seperti masyarakat dan tokoh antar etnis dari Kota Pontianak dan Kabupaten Kubu Raya, Kalimantan Barat. Selain itu, peneliti juga melakukan observasi berupa penelusuran dokumen- 
dokumen tambahan dan dokumentasi selama dilapangan dan catatan sejarah terdahulu. Teknik analisis data dilakukan secara kualitatif sejak pra penelitian, penelitian dan pasca penelitian.

\section{Hasil Penelitian dan Pembahasan}

Selama dua dekade, Kalimantan Barat terus berproses dengan kegiatan rekonsiliasi yang dilakukan oleh berbagai pihak. Kegiatan itu dilaksanakan dalam proses secara singkat maupun jangka panjang. Sampai sekarang, masih terdapat permukiman-permukiman yang dulunya sengaja disediakan oleh pemerintah setempat untuk menjadi tempat pengungsian sekaligus relokasi dari wilayah konflik.

Cerita mengenai proses reka adegan mengenai konflik etnis masa lalu masih tergambar dengan jelas oleh masyarakat sekitar, termasuk generasi muda, anak Kalimantan Barat. Sekarang sudah banyak pemukiman dan sekolah yang dipenuhi oleh anak-anak heterogen, tetapi kenangan akan cerita konflik masa lalu masih bisa mereka dapatkan, dimana saja termasuk dari keluarga anak-anak sendiri.

Saat ini, hampir semua generasi muda Kalimantan Barat mengetahui mengenai adanya berbagai konflik horizontal antar etnis. Kini, anak-anak beretnis Madura mengalami ketakutan, bahkan pelarangan dari keluarga terdekat ketika ingin memasuki salah satu wilayah konflik, yaitu Kabupaten Sambas, Kalimantan Barat. Tepat tahun 1997, kegaduhan terjadi ketika tersiar kabar bahwa ada konflik yang terjadi antara etnis Melayu Sambas dan Madura. Masyarakat Kalimantan Barat mengenal etnis Melayu di wilayah ini dengan sebutan "Sambas" yang berarti Melayu Sambas, sehingga masyarakat Kota Pontianak biasanya mengenal terdapat etnis Melayu sekaligus etnis Sambas.

Ketakutan masyarakat tergambar pada pernyataan seorang masyarakat bernama Hasanah yang merupakan warga asli Kota Pontianak beretnis Madura. Hasanah menceritakan mengenai kehidupan masyarakat Madura yang terkena dampak dari konflik etnis masa lalu. Dalam sejarahnya, etnis Madura mempunyai sejarah konflik dengan dua etnis terbesar di Kalimantan Barat, yaitu Dayak dan Melayu, bahkan dalam konflik dengan masyarakat Melayu sekitar 48.000 masyarakat Madura mengungsi di wilayah Kabupaten Pontianak (saat ini menjadi Kabupaten Mempawah) dan Kota Pontianak (Subro, 2011:20). Sampai saat ini, masih ada keluarga masyarakat Madura yang memberi larangan untuk anaknya berkunjung ke wilayah Kabupaten Sambas dengan alasan ketakutan dan keamanan anaknya, bahkan hal ini dikhususkan untuk anak-anak lakilaki beretnis Madura. Larangan tersebut dilakukan oleh ibu Hasanah kepada anaknya.

"berharapnya itulah orang kita kesana gak ada ancaman kadang-kadang kalau kita kesana itu dianggap penjahatkan, yang sebenarnya dia kok kita, kok jadi kita yang jadi kayak yang jahat" kata Hasanah (wawancara 24 Februari 2019, pukul 14.30 WIB)

Maulana (15) seorang anggota Forum Anak Kecamatan Pontianak Timur yang saat ini bersekolah di SMA Negeri 6 Pontianak, kehidupannya di sekolah dan di forum anak penuh dengan keberagaman. Indah (2016:292), Arendt menjelaskan mengenai Ultim yaitu kemampuan manusia untuk 
hidup bersama dalam perbedaan, kemudian hal ini dilakukan oleh Maulana sebagai anak Madura untuk beradaptasi dalam melakukan aktivitas sehari-hari bersama dengan temantemannya dari berbagai multietnis.

Proses kontruksi pengampunan Maulana diuji ketika dia diberikan video oleh saudaranya mengenai kekerasan yang dilakukan etnis Dayak terhadap etnis Madura sekitar dua dekade lalu di daerah Sampit, Kalimatan Tengah. Video tersebut diberikan ketika Maulana masih usia remaja.

"yahh... dulukan pernah dikasih video, itu madura kena bantai...gimana yahh, kalau misalnya keluarga sorang sih rasa marah itu ada karena keluarga sorangpun rasa dendam ada, rasa nak dibalas" Maulana (wawancara 24 Februari 2019, pukul 14.30 WIB)

Penyebaran informasi konflik etnis masa lalu melalui konten media seperti yang dialami Maulana membuat proses rekonsiliasi dan pengampunan menjadi terhambat, dikarenakan akan terjadi proses recalling atau ingatan memori kolektif mengenai konflik etnis masa lalu. Dibalik semua itu, Maulana memberikan pernyataan bahwa dia memaafkan kejadian tersebut dengan alasan bahwa kejadian tersebut sudah menjadi masa lalu.

Hannah Arendt menjelaskan bahwa memaafkan berguna untuk membatalkan perbuatanmasa laludan Maulanamenerapkan halini padakesadarannya bahwa, memaafkan atas dasar kejadian sudah berlalu walaupun masih ada rasa kewasapadaan akan konflik pada diri Maulana dan keluarganya sebagai perwakilan dari masyarakat etnis Madura.

Perspektif berbeda hadir dari masyarakat etnis lain, yaitu Hilaria Nugil, seorang anak perempuan keturunan Dayak siswi SMA
Negeri 2 Ambawang, Kabupaten Kubu Raya. Lahir dari seorang ayah keturunan Dayak daerah Ambawang Kabupaten Kubu Raya dan ibu keturunan Dayak wilayah Pahauman Kabupaten Landak. Anak etnis Dayak yang disapa Nugil ini pernah menjadi Presiden (ketua) Forum Anak Ambawang saat duduk di sekolah menengah pertama. Mengenai proses konstruksi pengampunan yang terjadi pada Nugil, puncaknya terjadi hampir sama dengan Maulana pada saat. Nugil pada usia remaja, mendengar cerita dari sang ibu mengenai konflik etnis Dayak dan Madura dalam konflik yang terjadi di desa Pahauman Kabupaten Landak.

"kalau mungkin itu dulu masih dalam usia gak tau umur berapa dan waktu itu kakek aku juga lagi sakit jadi ada cerita kalau misalnya madura sama dayak ini lagi ada perang gitulah jadi dulu yang jadi kayaknya yang dapat kekerasan itu anak bahkan anak-anak nih kayak dilemparin gitu ke atas "tuss" kayak pisaunya udah nunggu di bawah jadi dari situ anak yang dapat kekerasan itu anak madura jadi untuk mereka udah sekarang sih diwilayah Pahauman soalnya ditempat tinggal mama aku sekarang yang suku madura itu udah gak ada disana" kata Hilaria Nugil (wawancara dilakukan 1 Maret 2019, pukul 19.32 WIB)

Melalui cerita tersebut, kembali terjadi proses recalling sehingga generasi muda diperkenalkan mengenai kondisi konflik etnis masa lalu, proses ini secara pendekatan ilmiah dinamakan sebagai memori kolektif. Olick (1999:336) dalam Munsi (2016) menyampaikan tiga prinsip konsep memori kolektif, salah satunya adalah mendorong kita untuk melihat memori sebagai residu otentik akan masa lalu atau sebaliknya sebagai konstruksi yang sifatnya dinamis dalam masa kini.

Fine dan Beim (2007) dalam (Surayuda, 2016) memaparkan bahwa pendekatan 
tradisional membahas memori kolektif merupakan produk dari proses interaksi sosial. Gary A Fine (2007) menyarankan pendekatan yang lebih berorientasi pada proses, yaitu penelitian yang menggunakan interaksi antara agen dan memori kolektif yang dilembagakan objek, dan bagaimana interaksi menghasilkan skema dimana orang memahami masa lalu. Memori paling umum dimanifestasikan melalui kepercayaan dan monumen, tetapi memori juga melekat pada objek fisik sehari-hari.

Arendt (1958:7) memaparkan mengenai hidup manusia melakukan kegiatan dengan memproduksi sesuatu, sehingga hal yang diceritakan oleh ibunya Nugil membuat produksi ingatan mengenai proses konflik masa lalu terjadi dan otomatis generasi muda seperti Nugil merekam kejadian tersebut dan menjadi ingatan kolektif sampai saat ini. Posisi yang dipahami Nugil seakan menjadikan bahwa dirinya sebagai generasi keturunan etnis Dayak bersalah atas terjadinya konflik etnis masa lalu, karena diceritakan pada waktu itu masyarakat Dayak menjadi pelaku atas konflik antar etnis masa lalu.

Nugil menceritakan pengalamannya ketika ingin balik ke kampung halaman ibunya, di Desa Pahauman yang harus melalui aliran sungai di daerah Sungai Ambawang. keluarganya memperingati Nugil untuk berhati-hati karena dirinya akan melewati perkampungan etnis Madura yang diperkirakan merupakan para pengungsi konflik etnis Dayak dan Madura di Desa Pahauman sekitar dua dekade yang lalu.

“aa.. soalnya kemarin juga mama lagi ke pusk- esmaskan jadi ada ketemu nih sama orang madura dan dia bisa bahasa dayak jadi mama itu tau pasti dulu ini asalnya dulu dari Pahuman gitu, soalnya dia juga bilang dia bilangnya dari $\mathrm{Pa}$ human gitu pernah tinggal disana" kata Hilaria Nugil (wawancara dilakukan 1 Maret 2019, pukul 19.32 WIB)

Keberadaan pengungsi memang banyak ditemukan di satu daerah tertentu sehingga akan merasa aman dan hal tersebut merupakan upaya dari pemerintah daerah dalam melakukan resolusi konflik sekitar dua dekade yang lalu. Arendt (1958:240) menguraikan situasi kondisi mengenai memaafkan dimana yang pertama, memaafkan atas dasar pelanggaran yang dilakukan tanpa sadar dan kedua, memaafkan yang dilakukan atas dasar kemanusiaan. Pada kisah Nugil, dirinya memaparkan mengenai kesalahan yang dilakukan melalui perkataan yang tidak disengaja alias tanpa sadar dan kesalahan yang dilakukan akibat dari pengaruh mistis sehingga manusia melakukan hal tersebut tidak sepenuhnya dikuasai oleh kesadaran.

"kalau misalnya Nugil mikir dulu kalau gak salah itukan madura ini yang kayak bikin keributan dulu jadi kayak panglima-panglima dayak nih kayak emosi gitu jadi kalau misalnya aku mikir sekarang, kalau misalnya mengampuni gitu pasti diampuni sih soalnyakan itu dari setiap orang perkataannyakan gak sengaja gitukan ngucapin kayak gitu malah jadi peperangan antara suku jadi kalau misalnya kita paham gitu soal masalahnya gimana yah dikasih maaf sih" ungkap Hilaria Nugil (wawancara dilakukan 1 Maret 2019, pukul 19.32 WIB)

Nugil sebagai generasi muda keturunan Dayak saat ini memaafkan kejadian tersebut atas dasar kemanusiaan dan dirinya merasa bahwa masing-masing etnis harus mengintropeksi diri untuk kerharmonisan kedepannya. Leo Waldi seorang anak keturunan etnis Dayak yang merupakan 
Presiden Forum Anak Ambawang menceritakan pengalamannya mengenai keluarganya yang pernah mengungsi ke daerah Desa Pahauman, Kabupaten Landak.

"belum pernah sih cuman kakak dulu pernah cerita waktu konflik keluarga ini ngungsi di daerah pahuman kalau gak salah dulu dan kalau masalah keluarga atau masyarakat yang larang-larang dekat orang madura atau melayu sih, jarang-jarang yah tapi kalau gak salah pernah saya dengar takut kayak dapat sesuatu dari orang itu dari suku ini" Leo Waldi (wawancara dilakukan 1 Maret 2019, pukul 16.58 WIB)

Saat dikonfirmasi mengenai proses pengungsian keluarga Leo Waldi, Samsuyang merupakan ayah kandung dari Leo memilih untuk menghindar dari membahas mengenai konflik etnis, ayah Leo lebih memilih untuk tidak menyentuh pembicaraan mengenai situasi konflik tersebut sama sekali.

Reaksi yang dilakukan oleh Samsu merupakan bagian dari elemen dalam memberikan pengampunan dalam pengertian Arendt, komitmen untuk tidak menghendaki permusuhan yang merupakan akar dari pada pelanggaran. Pak Samsu dalam hal ini lebih memilih untuk menghindar dari upaya membongkar memori kolektif terkait hal ini, demi mereduksi kejadian fakta di masa lalu demi mempelancar pengampunan yang ada.

"disini memang, nah itukan awal-awalnya orang belum pernah merasakannya dengan cerita kerusuhan itu semua orang panik juga sebenarnya itukan hanya sekedar isu-isu bukan yang sebenarnya berawal dari situlah ternyata tidak terbukti apa yang diceritakan orang berawal disitulah masyarakat disini gak mau terima mentah-mentah" Samsu (wawancara dilakukan 1 Maret 2019, pukul 17.53 WIB)

Perspektif pengampunan individu selanjutnya datang dari Dimas Prayogo, seorang anak beretnis Melayu Pontianak yang saat ini bersekolah di SMA Negeri 5 Pontianak. Jika diibaratkan sebagai pelaku konflik, sikap dirinya sebagai generasi muda belum bisa menerima dan merupakan perasaan yang wajar terjadi, dikarenakan memang selama ini keluarganya bukan merupakan keturunan atau masyarakat yang merasakan secara langsung konflik etnis sekitar dua dekade yang lalu.

"kalau sama orang tua harap maklum kita gak terima mungkin Dimas gak tau karena Dimas belum pernah mengalami gimana perasaan kalau keluarga kita kenak, teman juga kenak gitukan yah mungkin bisa jadi Dimas juga ikut campur karena itu juga keluarga kita dan teman sebaya kita... kalau memang terbukti salah dan korbannya teman dekat kita mungkin bisa terjadi perpecahan" ucap Dimas Prayogo (wawancara 4 Maret 2019, pukul 16.09 WIB)

Proses pengampunan yang tengah terjadi dibutuhkan kerjasama dari semua pihak. Untuk itu, tidak hanya anak-anak sebagai generasi muda, peran serta masyarakat, tokoh masyarakat dan pemerintah daerah memegang tugas penting untuk mengawal proses rekonsiliasi. Kelurahan Siantan Tengah, Kota Pontianak, Kalimantan Barat menjadi salah satu wilayah yang banyak ditempati oleh para pengungsi, khususnya para masyarakat Madura yang direlokasi dari wilayah Kabupaten Sambas. Ibu Misjaya merupakan salah satu tokoh masyarakat yang saat ini dipercaya sebagai pendamping masyarakat wilayah sekitar Siantan Hulu dan sering membantu Dinas Sosial dalam melakukan sensus masyarakat yang prasejahtera di wilayah Siantan Tengah.

Pengalaman dalam melakukan sensus dan bercengkrama sehari-hari dengan masyarakat membuat Ibu Misjaya banyak berbincang dengan masyarakat korban konflik Sambas yang terjadi sekitar dua dekade yang lalu. Ibu Misjaya yang 
merupakan masyarakat beretnis Melayu Sambas menemukan pasangan hidup serta melakukan pernikahan silang dengan pria beretnis Madura, sehingga saat ini ibu Misjaya fasih dalam menggunakan bahasa Madura dalam kehidupan sehari-hari.

“....kita jugakan memaklumi keadaan mereka yah, mereka waktu yang kejadian itu misalnya suaminya dibunuh atau anaknya dibunuh jadi mereka pasti sedikit banyak mereka ada rasa trauma ada rasa sakit hati yang mungkin mereka simpan untuk kita sendiri kalau ibu nih tanggapin mereka gak sakit hati sih cuman yakinkan mereka bahwa kita disinikan gak seperti yang mereka pikirkan maksudnya kite nih gimana mereka bisa nilai kita kita ini baik gitu yah dengan sikap kita..." ujar Misjaya (wawancara 20 Februari 2019, pukul 16.54 WIB)

LatarbelakangkeluargakecilIbuMisjaya dengan adanya pernikahan campuran antara Melayu Sambas dan Madura membuat bukti mengenai pemahaman Arendt bahwa masyarakat pluralitas dapat menjadikan alat mempersatukan dalam perbedaan (manusia ultim), sehingga proses pengampunan yang terjadipun bisa memicu masa depan baru (Indah, 2016:292). Mengenai masyarakat yang tinggal di sekitar wilayah kediaman keluarga Misjaya yang merupakan korban konflik Sambas, Misjaya mengungkap bahwa masyarakat sudah pulih sekitar $80 \%$ dalam hal mengampuni. Hal ini terlihat dari sikap setiap warga Madura yang ingin menjalin relasi dan komunikasi dengan masyarakat sekitar, bahkan adanya pernikahan silang membuat hubungan antar masyarakat bisa terbuka secara individu satu dengan yang lain. Pernikahan silang ini justru dapat menghasilkan integrasi budaya sehingga jejak kepada generasi penerus kearifan lokal dapat terus dijaga di masa mendatang (Dasrun et al, 2017:163). "kalau yang didaerah kota sendiri yang ibu liat sih termasuk mereka $80 \%$ sudah pulih yah karena mereka sudah mau membaur lagi, mereka jadi masyarakat setempat setidaknya perkawinan silang itu masih banyak terjadi" ujar Misjaya (wawancara 20 Februari 2019, pukul 16.54 WIB)

Menjadi temuan menarik ketika adanya proses rekonsiliasi yang diusahakan semenjak masa pasca-konflik dinilai tidak berkelanjutan, sehingga hal tersebut membuat proses pengampunan justru mendorong masyarakat untuk mengampuni secara alamiah. Subro yang merupakan tokoh gerakan perdamaian sekaligus koordinator bidang budaya Ikatan Keluarga Besar Madura menilai, pemerintah daerah Kalimantan Barat harus belajar dari wilayah konflik Kalimantan Tengah yang menjadi pusat awal mula konflik Sampit antara Dayak dan Madura yang penanganan rekonsiliasi konfliknya sampai menyentuh tingkatan teknis, yaitu pendataan dan pengembalian aset korban konflik sehingga secara tidak langsung merupakan kemajuan berupa keadilan yang datang dari pemerintah daerah setempat.

Yuliyanto (2017:51) menjelaskan mengenai Provinsi Kalimantan Tengah yang memiliki Peraturan Daerah Nomor 16 Tahun 2008 mengenai pencegahan dan penghentian konflik. Di skala nasional melalui Direktorat Jenderal Peraturan Perundang- Undangan perlu menerbitkan Peraturan Pemerintah Pelaksanaan Undang-Undang Nomor 7 Tahun 2012 tentang Penanganan Konflik Sosial yang di dalamnya memuat pelibatan kelompok etnis (panata adat) dan tokohtokoh etnis dalam penanganan konflik sosial.

"Kalimantan kan kita pertemuan tahun 2001 itu sekitar bulan maret yah di Jakarta yang di 
inisiasi oleh Kemetrian Dalam Negeri bersama kantor-kantor Presiden saat itu dikumpulkan tokoh-tokoh ada kesepakatan damai kemudian dari pertemuan itu ada kemudian tindak lanjut untuk tingkat daerah, nah masing-masing itu meninjaklanjuti cuman memang tidak lanjutnya itu ada yang memang substansi atau yang memang ceremony nah saya melihat di Kalbar itu hanya ceremony di Kalteng itu menindaklanjuti langsung keteknis di lapangan sehinggakan Kalteng kemajuannya jauh lebih kongkret dibanding Kalbar yang sampai sekarang Kalbar gak ada kemajuan yang signifikan, walaupun sesungguhnya proses rekonsiliasi alami itu terjadi di masyarakat yah contoh sudah banyak cerita". Ulas Subro (wawancara dilakukan 17 Januari 2019, pukul 14.56 WIB)

Pernyataan ini di perkuat dengan analisis (Nutfa \& Anwar, 2015:141) yang memaparkan mengenai kegagalan rekonsiliasi masyarakat pasca konflik dalam proses rekonsiliasi belum sepenuhnya menyentuh akar konflik sehingga yang kemudian diperparah oleh terjadinya krisis kepercayaan (distrust) antar masyarakat sehingga kegagalan rekonsiliasi ini hanya dapat dilakukan dengan dibangunnya kembali proses perdamaian berjangka panjang yang berbasis kepercayaan (trust) yang bersifat keadilan untuk meminimalisir stereotip antar etnis.

Arendt (1958: 237), mengungkapkan mengenai memaafkan merupakan kemampuan manusia untuk menembus kesulitan ireversibilitas dimana ketidakmampuan untuk membatalkan kesalahan yang orang lain lakukan, lebih dalam lagi hal ini dikatakan sebagai usaha untuk membatalkan perbuatan masa lalu. Banyak sekali usaha-usaha yang dilakukan berbagai pihak khususnya setiap individu untuk membatalkan perbuatan masa lalu, yaitu konflik etnis yang terjadi sekitar dua dekade yang lalu. Arendt juga mengemukakan bahwa, pengampunan secara individu bisa membuat harapan untuk kehidupan di masa mendatang, sehingga yang dibutuhkan sekarang adalah menjaga keharmonisan terjadi di Kalimantan Barat khusunya untuk generasi muda saat ini, tetapi hal ini mempunyai tantangan kedepan di masa mendatang mengenai potensipotensi konfik yang ada.

Secara budaya perspektif proses pengampunan secara individu dihambat oleh adanya stereotipyang dihasilkan. Hal ini tentu sesuai dengan penjelasan Hannah Arendt (1958:240) mengenai nuansa emosional dari sisi psikologis yang merupakan bagian penting dari sisi fenomenologi pengampunan dimana pemantik emosi ini bisa dimunculkan melalu stereotip yang muncul di masyarakat, sehingga membuat proses pengampunan individual cenderung tidak sempurna. Subro berbagi pengalaman mengenai perjalanan dirinya dalam memberikan edukasi masyarakat dengan memahami materi mengenai pengetahuan budaya dan penelitian riset mengenai berbagai usaha rekonsiliasi.

“Ada satu penelitian menarik yang dilakukan oleh pak Zaenudin Isman (Alm.) pasca konflik sambas dia meneliti dua komunitas, satu di Sambas satu di Samalantan, satu basisnya melayu satu basisnya dayak dia tanya tentang sterotipe itu "bagaimana orang madura?" jawabannya jelek bahkan sampai $87 \%$ korepondennya yang bilang bahwa orang madura itu dengan segala sterotipenya tadi di Samalantan juga gitu di komunitas orang dayak tapi ketika di cross check menurut beliau dalam presentasenya berapa persen yang mengalami langsung, dia bilang apa angkanya 10-15\% bayangkan dari $87,10-15 \%$ berarti selebihnya adalah sterotipe yang beredar dari mulut-kemulut...." ungkap Subro (wawancara dilakukan 17 Januari 2019, pukul 14.56 WIB) 
Subro yang merupakan penulis buku "Suara Kami Buat Perdamaian" juga menceritakan mengenai pengalamannya dalam bertemu dengan seorang anggota dari sekelompok mahasiswa yang akan KKN (Kuliah Kerja Nyata) dan salah satu mahasiswa merupakan masyarakat beretnis Madura yang merasa takut untuk pergi menuju lokasi KKN. Hal ini terjadi karena, lokasi KKN merupakan wilayah yang pernah terjadinya konflik etnis, yaitu Kabupaten Sambas. Hal ini berkaitan dengan berkembangnya cerita di masyarakat seperti yang diceritakan oleh Ibu Hasanah, dimana anak laki-laki beretnis Madura dilarang untuk memasuki wilayah tersebut. Tetapi, dengan dorongan teman-temannya yang memberi motivasi bahwa keadaan saat ini sudah aman, akhirnya mahasiswa beretnis Madura tersebut bersedia untuk mengikuti KKN tersebut. Cerita akan peristiwa KKN tersebut membuat Subro yakin, bahwa, kunci rekonsiliasi terdapat di tangan generasi muda, beliau sudah membuktikan dirinya yang merupakan masyarakat etnis Madura sudah pernah mengunjungi lokasi konflik etnis seperti Kabupaten Sambas dan Kabupaten Landak tetapi tidak terjadi apaapa walaupun rasa waspada tidak dapat dipungkiri dari seorang pribadi Subro.

Stereotip ini sesuai dengan pengertian yang dibahas oleh (Hardiman, 2003:25) bahwa manusia bisa percaya begitu saja dengan hal yang rutin dilakukan oleh sehari-hari sehingga menghasilkan ketidakseimbangan secara teori dan praktek, sehingga wajar jika Subro memberi informasi dari $87 \%$ hanya sekitar $10 \%-25 \%$ yang memang mengalami kejadian konfliknya tersebut sisanya hanyalah Stereotip yang tidak bisa dibuktikan realitasnya (praktik).

"nah... ini agak susah kita melihat karena ini persoalan tadi kita katakan secara umum kelihatan sudah tenang dan sudah redup tetapi hati didalam orangkan kita gak bisa tau, saya secara teori kita mengatakan sih itu pasti masih ada kebencian dendam masa lalu pasti ada, karena itu tidak mudah di hapus tapi ini tidak muncul kepermukaan karena tidak ada yang memicu kalau ada yang memicunya, ada yang memprovokasinya bisa saja sewaktu-waktu muncul lagi itu yang dalam bahasa saya tadi keliatan tenang airnya bukan berarti tidak ada bahaya didalamnya, mungkin dibawah sana arus itu masih ada, karena menyangkut dulu masa lalu yang kelam itukan pasti hati didalam tiap-tiap orang itukan masih ada jadi pembesar kebencian, nah ini yang tidak mudah dilihat kita sebagai seorang ilmuan teoritisi kita selalu memperkirakan bahwa konflik itu bisa sewaktu-waktu muncul apabila ada salah saja dalam mengelola masyarakat itu misalnya adanya ketidakadilan itu bisa muncul..." ulas Prof. Dr. Yohanes. (wawancara dilakukan 24 Januari 2019, pukul 7.37 WIB)

Prof. Dr. Yohanes Bahari, M.Si. saat ini merupakan Guru Besar Falkutas Keguruan dan Ilmu Pendidikan di Universitas Tanjungpura Pontianak, dari segi akademisi beliau mempunyai perspektif tambahan mengenai hambatan terjadinya pengampunan secara menyeluruh yaitu dengan adanya potensi konflik yang bisa terjadi kapanpun dan dimanapun dalam hal ini diumpamakan seperti permukaan air yang terlihat tenang tetapi kita tidak tahu dalam hati manusia individu memikirkan apa. Keseluruhan konflik yang terjadi pada dasarnya menganggu mobilitas sosial, ekonomi, politik, bahkan keamanan selama puluhan tahun (PU, 2017:1). Ketidakadilan yang dialami berbagai etnis dari segala aspek seakan bisa menjadi pemicu utama konflik untuk muncul kembali.

Keseluruhan proses pengampunan digambarkan melalui model pengampunan 
gambar 2 melalui paparan stereotip menjadi tahap pertama yang harus di selesaikan dengan baik, karena masyarakat yang masih banyakmemilih percaya dengan pembicaraan dari mulut-kemulut (vita contemplativa) dan konten media yang megandung tragedi konflik sehingga membuat gambaran antar kelompok etnis menjadi tidak baik khususnya kelompok-kelompok etnis yang pernah saling berkonflik. Selanjutnya, proses tindakan (vita activa) pengampunan individual bisa terbagi menjadi dua yaitu pengampunan atas konflik masa lalu dan pengampunan atas stereotip yang diterima oleh generasi muda yang menjadi keturunan etnis yang pernah berkonflik.

Selanjutnya, dengan proses pengampunan yang masih berjalan membuat masyarakat rentan terhadap konflik yang bisa muncul dalam situasi dan kondisi apapun, sehingga perlunya keadilan yang menyeluruh untuk setiap kelompok etnis mendapatkan haknya sebagai seorang individu untuk menjaga hubungan antar etnis (ultim) agar lebih baik sehingga keharmonisan itu dapat terjadi secara berkelanjutan.

\section{Simpulan}

Proses perjalanan panjang yang dilalui masyarakat Kalimantan Barat selama dua dekade menjadi perhatian khusus bagi semua pihak, bukan hanya generasi muda tetapi masyarakat, tokoh antar etnis, dan pemerintah turut mengambil bagian dalam porsinya masing-masing.

Hubungan yang dibangun generasi muda secara kolektif membantu proses pengampunan terjadi secara alamiah. Hubungan pertemanan antar etnis menjadi proses lunturnya stereotipe yang ada selama ini di masyarakat. Di sisi lain, alkulturasi budaya seperti penguasaan bahasa antar etnis dan perkawinan campuran menjadi cara alamiah terjadinya pengampunan individual.

Adapun yang menjadi perhatian bersama ketika proses pengampunan ini menghadapi tantangan kehadiran memori

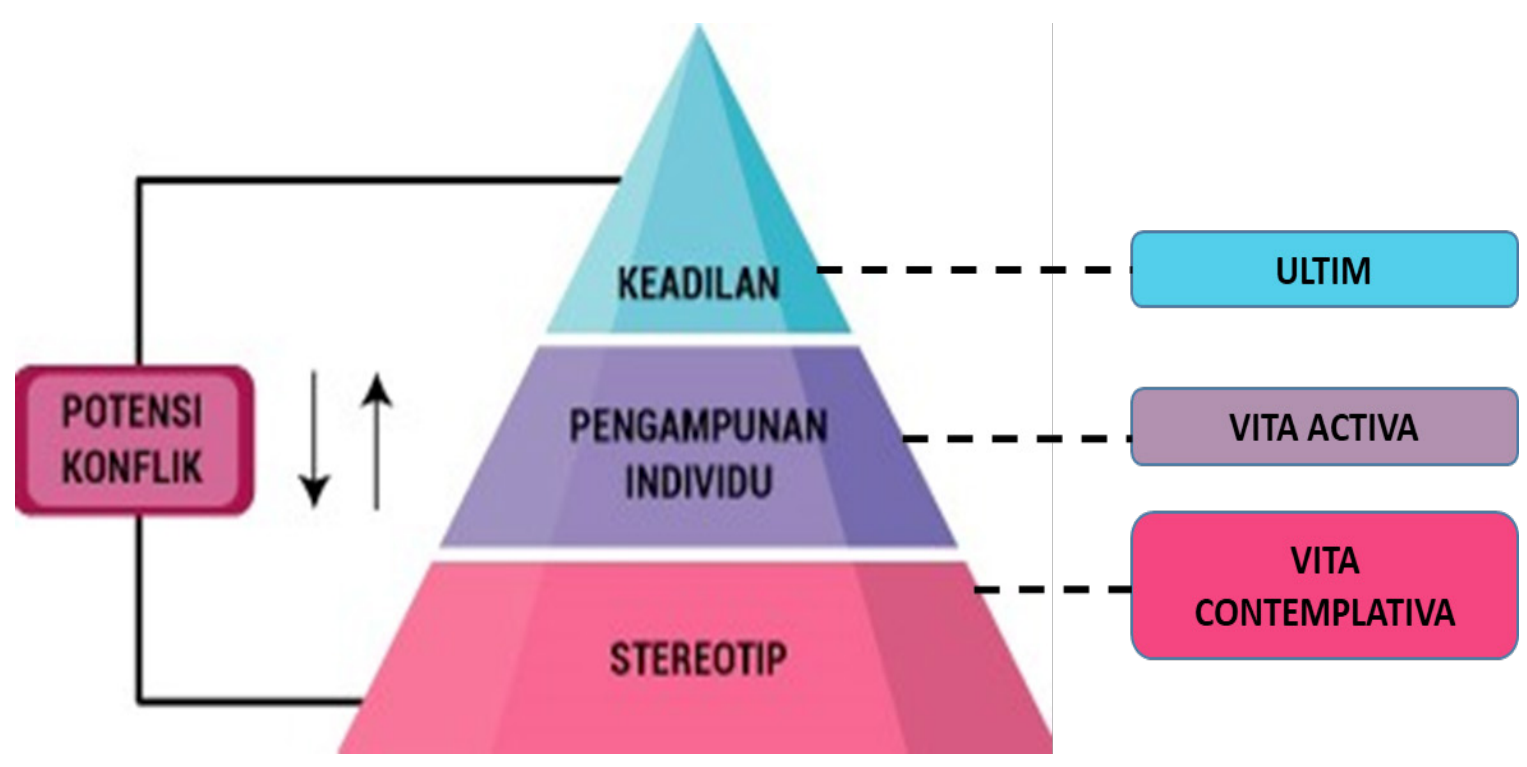

Gambar 2 Model Pengampunan Konflik Etnis di Kalimantan Barat Sumber: Olahan Peneliti, 2018 
kolektif berupa paparan konten media dan cerita yang beredar di masyarakat mengenai peristiwa konflik etnis. Selain itu, kuatnya paparan stereotip di lingkungan masyarakat homogen menjadi tantangan terbesar saat ini dalam menghasilkan pengampunan alamiah.

Penelitian ini menemukan model pengampunan yang merepresentasikan peningkatan paparan stereotip membuat proses pengampunan dan keadilan antar masyarakat etnis menjadi termarjinalkan, sebaliknya, semakin berkualitas penegakan keadilan antar masyarakat etnis membuat meningkatnya proses pengampunan atas konflik etnis masa lalu dan menguranggi terpaan stereotip pada generasi muda Kalimantan Barat. Penelitian ini menyarankan kepada seluruh masyarakat, tokoh antar etnis, dan pemerintah daerah Kalimantan Barat untuk berkolaborasi dalam proses rekonsiliasi yang masih terjadi sampai pada saat ini. Penelusuran aset korban, adanya wadah forum perdamaian yang berkelanjutan, sampai lahirnya kebijakan yang setara bagi seluruh masyarakat etnis menjadi harapan untuk terciptanya masyarakat adil dan makmur di Kalimantan Barat.

\section{Ucapan Terimakasih}

Apresiasi setinggi-tingginya untuk semua lembaga yang berkontribusi untuk penelitian ini seperti Institut Dayaklogi (www. dayakologi.id), Ikatan Keluarga Besar Madura, Forum Anak Kalimantan Barat, Forum Anak Kota Pontianak, dan Forum Anak Kabupaten Kubu Raya yang bersedia terlibat secara langsung dalam proses selama penelitian ini berlangsung. Terimakasih untuk program studi
Magister Ilmu Komunikasi Universitas Bunda Mulia dan Kementerian Riset, Teknologi, dan Pendidikan Tinggi (Kemenristekdikti) melalui Hibah Penelitian Tesis Magister berdasarkan Keputusan Direktur Jendral Penguatan Riset dan Pengembangan Nomor 7/E/KPT/2019 yang menunjang operasionalisasi penelitian ini sampai selesai pada akhirnya. Tidak lepas ucapan terimakasih kami apresiasikan kepada Jurnal Komunikasi ASPIKOM yang memberikan wadah bagi kajian bidang Ilmu Komunikasi untuk berkontribusi menyalurkan pesan perdamaian pada masyarakat Kalimantan Barat.

\section{Daftar Pustaka}

Ahimsa-Putra, H. S. (2012). FENOMENOLOGI AGAMA : Pendekatan Fenomenologi untuk Memahami Agama. Walisongo, 20(November 2012), 271-304.

Aminullah, Puji Lestari, S. T. (2015). Model Komunikasi Antarbudaya Etnik Madura. Jurnal Komunikasi ASPIKOM, 2(0274), 272-281.

Anshorie, A., Anshorie, A., Antar, M., Komunitas, A., Barokah, P., Loa, S., \& Samarinda, B. (2015). Keharmonisan Antar Anggota Komunitas Pengajian Barokah Sekumpul Mushola Ar-Raudah Loa. 3(4), 361-371.

Arendt, H. (1958). The Human Condition. Chicago: U of Chicago Press.

Arkanudin. (2006). Menelusuri Akar Konflik Antaretnik. Mediator: Jurnal Komunikasi, 7(2), 185-194. https://doi. org/10.29313/MEDIATOR.V7I2.1276

BPS. (2010). Penduduk Menurut Kelompok Umur dan Jenis Kelamin. Retrieved June 13, 2019, from https:// sp2010.bps.go.id/index.php/site/ tabel? tid $=336 \&$ wid $=6100000000$ 
Dasrun, H., Kuswarno, E., Zubair, F., \& Hafiar, H. (2017). Negosiasi Citra Budaya Masyarakat Multikultural. Jurnal ASPIKOM, 3(2), 157-172. Retrieved from http://jurnalaspikom.org/ index.php/aspikom/article/view/125/119

Gary A Fine, A. B. (2007). Introduction: Interactionist Approaches to Collective Memory. Symbolic Interaction, 30(1), 1-5. https://doi.org/https://doi. org/10.1525/si.2007.30.1.1

Haba, J. (2012). ETNISITAS, HUBUNGAN SOSIAL DAN KONFLIK DI KALIMANTAN BARAT. 14(1), 31-52.

Hardiman, B. (2003). Heidegger dan Mistik Keseharian. Yogyakarta: Kanisius.

Indah, A. V. (2016). Jatidiri Manusia Berdasarkan Filsafat Tindakan Hannah Arendt Perspektif Filsafat Manusia: Relevansi Dengan Pelanggaran Ham Tahun 1965-1966 Di Indonesia. Jurnal Filsafat, 25(2), 277. https://doi. org/10.22146/jf.12686

Jansson, I., Wagman, P., Jansson, I., \& Wagman, P. (2017). Hannah Arendt' s vita activa : A valuable contribution to occupational science Hannah Arendt' $s$ vita activa: A valuable contribution to occupational science. Journal of Occupational Science, 0(0), 1-12. https://doi.org/10.1080/144275 91.2016.1277780

Kreber, C. (2014). Incorporating ACCESS The 'Civic-minded 'Professional? An exploration through Hannah Arendt 's ' vita activa.' Educational Philosophy and Theory, (June 2015), 37-41. https://doi. org/10.1080/00131857.2014.963492

Minza, W. M. (2012). Migran Muda dan Transisi dari Pendidikan ke Dunia Kerja. Jurnal Studi Pemuda, 13(1), 153-164.

Munsi, H. (2016). Dari Masa Lalu ke Masa Kini: Memori Kolektif, Konstruksi Negara dan Normalisasi Anti-Komunis.
ETNOSIA : Jurnal Etnografi Indonesia, 1(1), 30-43. https://doi.org/10.31947/ etnosia.v1i1.998

Nutfa, M., \& Anwar, S. (2015). Membangun Kembali Perdamaian: Rekonsiliasi Konflik Komunal Berbasis Trust. Kritis, 1(1), 133-142.

Pettigrove, G. (2006). Hannah Arendt and Collective Forgiving. Journal of Social Philosophy, 37(4), 483-500. https://doi. org/10.1111/j.1467-9833.2006.00353.x

Prayudi. (2004). Akar Masalah Penyebab Konflik Etnis Dan Alternatif Penyelesaiannya. Ketahanan Nasional, 9, 39-59. Retrieved from https://jurnal. ugm.ac.id/jkn/article/view/22154/14788

PU, E. J. (2017). Konflik Etnis Sambas Tahun 1999 Arah Disintegrasi Bangsa. Jurnal Kalpataru, 03(01), 1-10. https://doi.org/ http://dx.doi.org/10.31851/kalpataru. v3i1.1605

Rahino, R. P. (2017). Kalimantan Barat Disiapkan Jadi Ibukota Negara? Ini Tanda-tandanya Artikel ini telah tayang di tribunpontianak.co.id dengan judul Kalimantan Barat Disiapkan Jadi Ibukota Negara? Ini Tanda-tandanya, https:// pontianak.tribunnews.com/2017/10/09/ kalimantan-ba.

Subro. (2011). Suara Kami Buat Perdamaian. Pontianak: Cordaid-Caireu-YSDKSTAIN Pontianak Press.

Supriyadi, Y. (2011). Konflik di Kalimantan Barat. Retrieved from http://www. akademikayak.com/2008/03/ tentangkonflik-di-kalbar. html

Surayuda, R. J. (2016). Pusat Komunitas dan Kontestasi Memori Kolektif: Studi Kasus Ruang Publik Terpadu Ramah Anak (RPTRA) Kenanga di Cideng, Jakarta Pusat. Jurnal Masyarakat, 21(80), 233-261. 
Ulum, R. (2013). PROSPEK PEMBANGUNAN MASYARAKAT PASCA KONFLIK SAMBAS. Jurnal Analisa, 20, 25-35.

Yuliyanto. (2017). Peranan Hukum Adat Masyarakat Dayak dalam Menyelesaikan Konflik untuk Mewujudkan Keadilan dan Kedamaian. Jurnal Rechts Vinding, 6(1), 37-52.

Zakiyah. (2017). Cendekiawan Muslim Dan Wacana Konflik Etnis di Kalimantan Barat. Jurnal Panangkaran, 1(2), 144-147. 